\title{
Health complication caused by protein deficiency.
}

\author{
Alamgir Khan ${ }^{1 *}$, Salahuddin Khan ${ }^{1}$, Aftab Ahmad Jan², Manzoor Khan ${ }^{3}$ \\ ${ }^{1}$ Department of Sports Science \& Physical Education, Gomal University, Khyber Pakhtoonkhwa, Pakistan \\ ${ }^{2}$ Department of Pharmaceutical Chemistry, Faculty of Pharmacy, Gomal University, Khyber Pakhtoonkhwa, Pakistan \\ ${ }^{3}$ Hazara University Manshera, Khyber Pakhtoonkhwa, Pakistan
}

\begin{abstract}
Human body need to consume the sufficient amount of protein on daily basis. Lacking of sufficient intake of protein may cause many health complications. This short review aimed to assess the perceptions of various researchers available in the shape of literature about the health complications caused by low intake of protein. Based on available literature the researcher arrived at conclusion that insufficient of protein may cause various health problems such as kwashiorkor, marasmus, impaired mental health, edema, organ failure, wasting and shrinkage of muscle tissues, and weakness of immune system.
\end{abstract}

Accepted on October 04, 2017

\section{Protein Deficiency}

According to Rosendaal protein deficiency is a disorder of blood coagulating. The individual with the protein deficiency are at high risk of developing abnormal blood coagulation [1]. The person with moderate protein deficiency is at risk of deep vein thrombosis which occurs in deep veins of extremities [2].

\section{Health Complication Caused by Protein Deficiency}

Protein is a macronutrient that is basic for the development, upkeep and repair of all your body's cells. Body can't make due without this supplement [3]. Neglecting to devour enough protein can have various negative symptoms and eventually prompts demise. The author further stated the following health complications caused by low intake of protein.

\section{Kwashiorkor}

Kwashiorkor is a sort of protein inadequacy that influences youngsters. It has various manifestations which incorporate an extended liver, a swollen midriff, pedal oedema (swollen feet), skin depigmentation, skin aggravation, diminishing hair and tooth misfortune. At last, it can repress a youngster's mental and physical advancement.

\section{Marasmus}

Marasmus is a kind of protein inadequacy that can prompt weakness, muscle squandering, and lessened muscle versus fat levels, decreased vitality levels and weight reduction. It additionally diminishes the viability of the invulnerable framework and makes sufferers more helpless to infections.

\section{Impaired mental health}

Long term protein inadequacy can influence your psychological well-being in various ways. It can prompt mental hindrance (especially in youngsters) and furthermore cause tension, surliness, sorrow and crankiness.

\section{Oedema}

Not getting enough protein can prompt oedema (liquid maintenance). This can cause swelling in various zones of the body, for example, the feet, hands and stomach. Aside from the swelling oedema can likewise cause hurting in the appendages, stained skin, hypertension and solid joints.

\section{Organ failure}

Protein is required for the growth and maintenance of various body function. Deficiency of protein can cause the improper function of different body organs.

\section{Wasting and shrinkage of muscle tissues}

When you don't get enough protein in your eating regimen your body begins to source it from somewhere else. One of the primary sources your body swings to is the muscles. On the off chance that your body takes protein from the muscles it makes them wasting and shrinkage.

\section{Weak immune system}

Protein is basic for the creation of antibodies which are a key piece of the safe framework. On the off chance that you wind up plainly inadequate in protein your body will be not able produce these antibodies. This makes you more defenseless to disease as your body will battle to battle remote items.

\section{Conclusion}

Based on available literature the researcher arrived at conclusion that insufficient of protein may cause various health problems such as kwashiorkor, marasmus, impaired mental health, edema, organ failure, wasting and shrinkage of muscle tissues, and weakness of immune system.

\section{References}

1. Rosendaal FR. Venous thrombosis: A multicausal disease. The Lancet. 1999;3:1167-1173.

2. Saber AA, Aboolian A, LaRaja R, et al. HIV/AIDS and the risk of deep vein thrombosis: A study of 45 patients 
with lower extremity involvement. The American Surgeon. 2001;67(7):645-647.

3. Shryer D. Body fuel: A Guide to Good Nutrition. Singapore: Marshall Cavendish. 2007.

*Correspondence to:

Alamgir Khan

Department of Sports Science \& Physical Education

Gomal University

Khyber Pakhtoonkhwa

Pakistan

Tel: 03329741015

E-mail: alamgir1989@hotmail.com 